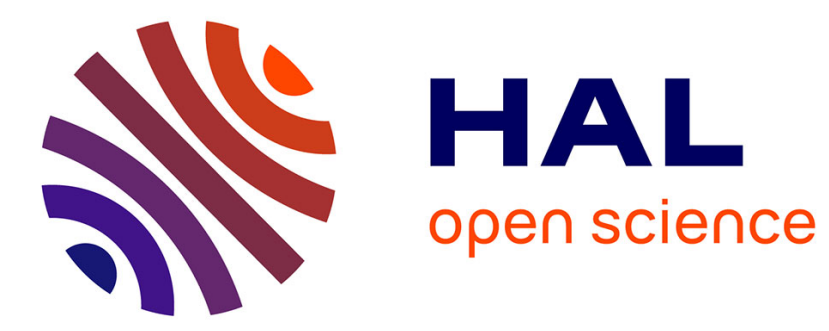

\title{
CO2/N2 Reverse Selective Gas Separation Membranes: Technological Opportunities and Scientific Challenges
}

\author{
Eric Favre, Denis Roizard, Roda Bounaceur, William J. Koros
}

\section{To cite this version:}

Eric Favre, Denis Roizard, Roda Bounaceur, William J. Koros. CO2/N2 Reverse Selective Gas Separation Membranes: Technological Opportunities and Scientific Challenges. Industrial and engineering chemistry research, 2009, 48 (7), pp.3700-3701. 10.1021/ie801923w . hal-01168987

\section{HAL Id: hal-01168987 \\ https://hal.science/hal-01168987}

Submitted on 20 Feb 2020

HAL is a multi-disciplinary open access archive for the deposit and dissemination of scientific research documents, whether they are published or not. The documents may come from teaching and research institutions in France or abroad, or from public or private research centers.
L'archive ouverte pluridisciplinaire HAL, est destinée au dépôt et à la diffusion de documents scientifiques de niveau recherche, publiés ou non, émanant des établissements d'enseignement et de recherche français ou étrangers, des laboratoires publics ou privés. 


\title{
$\mathrm{CO}_{2} / \mathrm{N}_{2}$ Reverse Selective Gas Separation Membranes: Technological Opportunities and Scientific Challenges
}

\author{
Eric Favre, ${ }^{*}{ }^{\dagger}$ Denis Roizard, ${ }^{\dagger}$ Roda Bounaceur, ${ }^{\dagger}$ and William J. Koros ${ }^{\ddagger}$ \\ LSGC-UPR CNRS 6811, ENSIC, Nancy Université, 54001 Nancy, France, and School of Chemical and \\ Biomolecular Engineering, Georgia Institute of Technology, Atlanta, Georgia
}

Sir: A reverse selective $\mathrm{CO}_{2} / \mathrm{N}_{2}$ membrane material has been recently reported by Kumar et al. in this journal. ${ }^{1}$ We would like to follow up on this publication with additional information that is related to this unusual experimental observation. To our knowledge, a $\mathrm{CO}_{2} / \mathrm{N}_{2}$ reverse selective membrane material has not been reported previously and would be a breakthrough both from the scientific and technological point of view.

Such a $\mathrm{N}_{2}$ selective membrane would be of major interest for postcombustion carbon dioxide capture (i.e., from flue gas) which requires a purity of 0.9 (or more) together with a capture ratio of 0.9 (or more). We show in Figure 1 some simulation results performed through classical design computations for gas permeation processes ${ }^{2}$ where a reverse selective material is compared to a classical one for a single stage permeation situation. First, when a pressure ratio of 0.01 is applied (Figure 1a), a selectivity of 300 or more is needed for a normal selective material to reach key targets, while a selectivity of 50 is enough with a reverse selectivity material. The most interesting performance of a reverse selective material can be pointed out when a moderate pressure ratio is applied. This condition is necessary in order to minimize the energy consumption, which is of primarily importance for the separation process to be selected for this application. Calculations classically show that a pressure ratio in the range of 0.1 can be tolerated. ${ }^{3}$ In that case (Figure 1b), a reverse selective material is the only one which achieves the target performance, again with a separation factor around 50. Additionally, carbon dioxide will be recovered in that later case on the high pressure side (i.e., retentate side). This capability is very interesting since carbon dioxide has to be compressed afterward to up to 80-150 bar for transport purposes in a carbon capture and storage framework. A supplementary energy gain is thus obtained, compared to $\mathrm{CO}_{2}$ selective materials which require permeate vacuum pumping to be operated.

Despite its attractiveness, to our knowledge, no theoretical basis for a nitrogen selective permeation process through a membrane material, be it dense or porous, has been reported. The report by Kumar et al. ${ }^{1}$ does not offer a real mechanistic explanation of the basis for a faster $\mathrm{N}_{2}$ permeability compared to $\mathrm{CO}_{2}$. Concerns that existed in explaining such results included the following:

1. Given the kinetic diameters of $\mathrm{CO}_{2}$ and $\mathrm{N}_{2}, \mathrm{CO}_{2}$ should always show a higher diffusion coefficient in materials showing molecular sieving properties or any conventional activated diffusion process that we can imagine.

* To whom correspondence should be addressed. Tel.: (33) 383175 390. Fax: (33) 383322 975. E-mail: Eric.Favre@ensic.inpl-nancy.fr.

Nancy Université.

Georgia Institute of Technology.
2. On the basis of point 1 , it seems that in a dense polymeric matrix (i.e., in the case of a complete filling of the pores of the material by polyetherimide (PEI)), no steady state selectivity in favor of nitrogen can be expected, be it in rubbery or glassy polymers.

3. Any surface effect (adsorption, surface flow) or phase change (capillary condensation) would be again in favor of $\mathrm{CO}_{2}$, due to its larger condensability.

4. The influence of a chemical reactivity between $\mathrm{CO}_{2}$ and PEI could lead to some specific retardation effect, but this would take place only under transient state conditions. To that respect, we report in Figure 2 an example of experimental results obtained on a PEI containing dense polymeric membrane operated under cyclic unsteady state conditions (repeated timelag experiments). A very large time lag is observed for the first
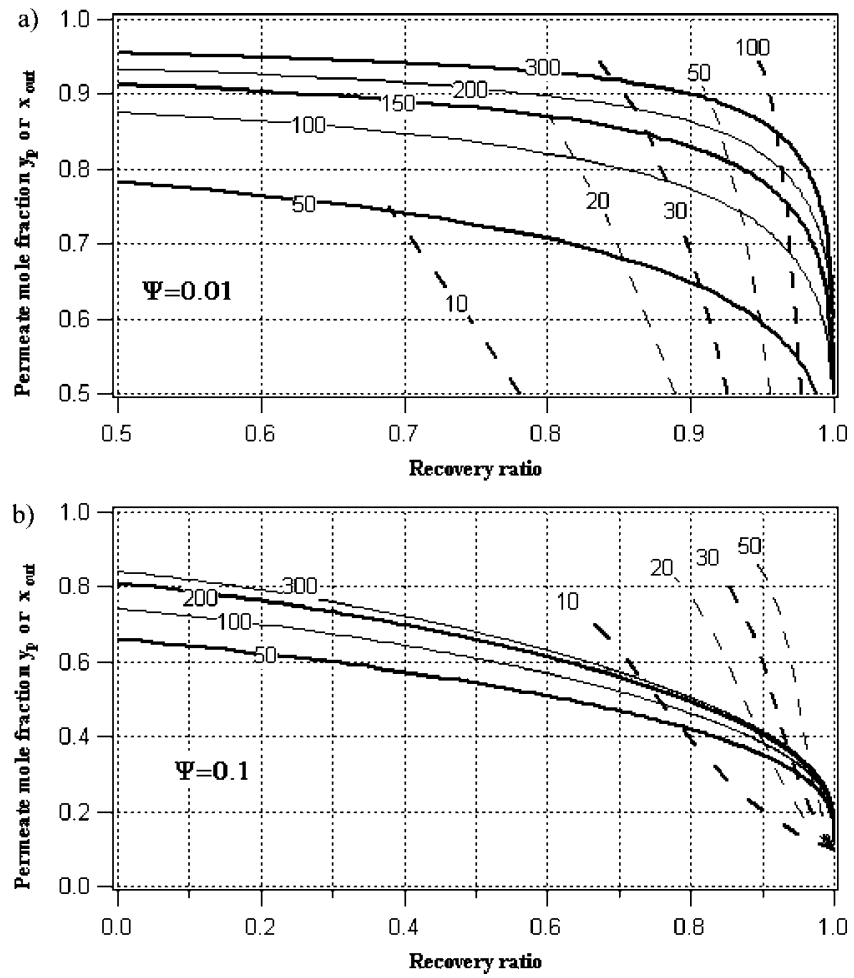

Figure 1. Simulation of the separation performance of a single stage membrane module operated under cross plug flow conditions for the recovery of carbon dioxide diluted in nitrogen (feed composition $10 \% \mathrm{~mol}$ fraction $\mathrm{CO}_{2}$ ) with a $\mathrm{CO}_{2}$ selective (lines) and a $\mathrm{N}_{2}$ selective material (dotted lines). Carbon dioxide outlet purity corresponds to the permeate composition (y) for the $\mathrm{CO}_{2}$ selective material and to the retentate composition ( $\left.x_{\mathrm{OUT}}\right)$ for the $\mathrm{N}_{2}$ selective material. For carbon capture application, a purity of 0.9 and a recovery ratio of 0.9 are needed. Two different values of the pressure ratio $\psi$ (downstream/upstream pressure) have been tested: (a) $\psi$ $=0.01$; (b) $\psi=0.1$. 


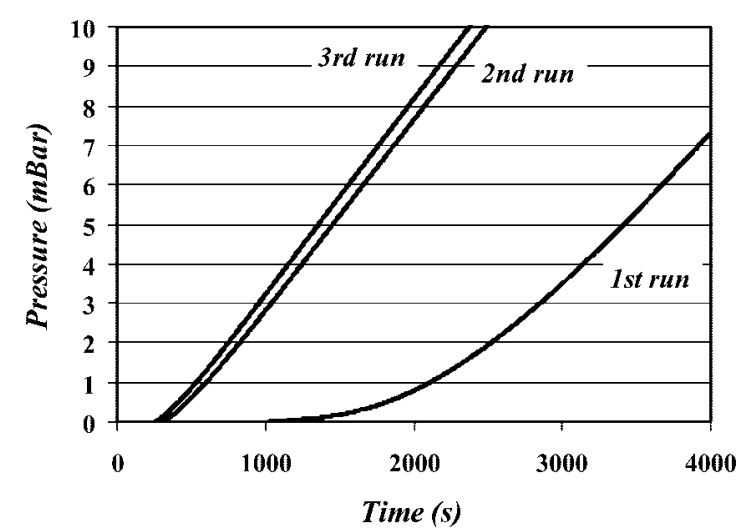

Figure 2. Incidence of PEI- $\mathrm{CO}_{2}$ chemical reactivity on the transient permeation through a dense polymeric membrane and repeated time-lag experiment performed under the following conditions: temperature $25^{\circ} \mathrm{C}$; upstream pressure 2 bar pure $\mathrm{CO}_{2}$; downstream pressure 0 at time zero; membrane cellulose propionate/polyetherimide (PEI 18\%) dense membrane, $55 \mu \mathrm{m}$ thickness. After each run, the downstream pressure was quickly decreased to zero by vacuum pumping and the next run was started.

cycle, due to the retardation effect exerted by the $\mathrm{CO}_{2}$ specific chemical reaction. $\mathrm{N}_{2}$ will breakthrough faster than $\mathrm{CO}_{2}$ under these conditions, and a reverse selectivity is temporarily obtained. This effect is annihilated afterward, and a classical $\mathrm{CO}_{2}$ selectivity is obtained when further cycles are operated without integral regeneration of the sorption sites. Nevertheless, given the time scale of the experiments reported by Kumar et al. (i.e., $170 \mathrm{~h}$ ), transient behavior could be expected to be unlikely to take place.

5. The only mechanism that we can currently suggest that predicts a faster $\mathrm{N}_{2}$ permeability is Knudsen flow, but with a very low selectivity (ca. 1.28) compared to the results which are reported (selectivity up to 80 ).

The above analysis may be overlooking some multicomponent effects or subtle coupling phenomena (i.e., role of water) in the process. We hope that this note will stimulate the curiosity and the efforts of the scientific community to explore what we consider to be an important and challenging scientific issue.

\section{Literature Cited}

(1) Kumar, P.; Kim, S.; Ida, J.; Guliants, V. V. PolyethyleneimineModified MCM-48 membranes: Effect of water vapor and feed concentration on $\mathrm{N}_{2} / \mathrm{CO}_{2}$ selectivity. Ind. Eng. Chem. Res. 2008, 47, 201.

(2) Bounaceur, R.; Lape, N.; Roizard, D.; Vallières, C.; Favre, E. Membrane processes for post-combustion carbon dioxide capture: a parametric study. Energy 2006, 31 (14), 2220.

(3) Favre, E. Carbon dioxide recovery from post combustion processes: Can gas permeation membranes compete with absorption. J. Membr. Sci. 2007, 294, 50.

IE801923W 